KESANS : International Journal Of Health and Science e-ISSN : 2808-7178, p-ISSN : 2808-7380

Web : http://kesans.rifainstitute.com/index.php/kesans/index

\title{
Recognizing Sexually Transmitted Infections And Their Treatment
}

\section{Nabilla Septiana, Dinie Ramdhani Kusuma, Yunita Hapsari}

Faculty of Medicine, University of Mataram, Indonesia

bilaseptiana04@gmail.com, diniekusuma@gmail.com, dr.yunitahapsari@gmail.com

\section{Article Information}

Accepted : 09 Nov

2021

Submitted :12 Nov

2021

Online Publish: 20 Nov

2021

\begin{abstract}
Sexually Transmitted Infections (STIs) are diseases that can be transmitted from one person to another, can be caused by bacteria, viruses, parasites, and fungi. STIs can be transmitted through vaginal, anal, and oral sex. This article aims to identify STIs and their management. The sources used are scientific journals and textbooks. Source searches were conducted on the online portals of journal publications such as the National Center for Biotechnology Information / NCBI (ncbi.nlm.nih.gov) and Google Scholar (scholar.google.com). Transmission of STIs can occur due to interactions between agents (disease-causing factors), hosts (humans as hosts), and the environment (environmental factors). The increase in the incidence of STIs is influenced by several factors, including demographic changes such as very high population growth, increased community movements due to work or tourism, advances in IT-based technology (Technology Information), and socio-economic improvements.
\end{abstract}

Keywords: Sexually Transmitted Infections; Signs and symptoms of STIs; STI transmission; STI prevalence; STI management 
Recognizing Sexually Transmitted Infections And Their Treatment

\section{Introduction}

Sexually transmitted infections (STIs) are diseases that can be transmitted from one person to another, can be caused by bacteria, viruses, parasites, and fungi. STIs can be transmitted through vagina, anal and oral sex. STIs can be classified based on their cure, curable STIs, namely Syphilis, Gonorrhea, and Trichomoniasis, while STIs that cannot be cured but can be alleviated with treatment, namely Hepatitis B, Herpes, Human Immunodeficiency Virus (HIV), and Human Papilloma Virus (HPV). (Puspita, 2017)

The prevalence of STIs is increasing every year and their spread is more evenly distributed throughout the world. The prevalence of STIs in South and Southeast Asia is 151 million cases, Africa is around 70 million cases, Australia and New Zealand is 1 million cases. Promiscuous and high-risk behavior is thought to be a factor that increases the prevalence of these STIs. (Diniarti \& Felizita, 2019)

In diagnosing STIs related to time constraints, availability of resources, financing, and affordability of treatment, the handling of STI cases based on a syndrome approach is carried out through identifying a group of complaints and symptoms as easily recognizable syndromes, and then determining the treatment for most or almost all microorganisms. -organisms are believed to be the cause of the syndrome. (Aditama et al., 2011)

\section{Research Methods}

The writing of this article uses various types of sources from scientific journals and textbooks. Source searches were conducted on the online portals of journal publications such as the National Center for Biotechnology Information / NCBI (ncbi.nlm.nih.gov) and Google Scholar (scholar.google.com).

Keywords used "Sexually transmitted infection. "Signs and symptoms of STIs", "Reproductive health", "STIS prevalence", "STIs management".

\section{Discussion}

\section{Definitions}

STIs are infections that are transmitted primarily through sexual contact. The mode of transmission can not only occur through the genito-genital course but can occur anogenitally or oro-genitally. Not all STIs are transmitted through sexual intercourse, but there are STIs that can be transmitted through direct contact with contaminated equipment and from pregnant women to their unborn babies or during childbirth. The term STD (Sexually Transmitted Disease) was previously used for sexually transmitted diseases, 
Recognizing Sexually Transmitted Infections And Their Treatment

but since STDs are not always symptomatic and mostly caused by infection, the term STD was changed to STIs. (Menaldi, 2015)

\section{Epidemiology}

In 2016, the World Health Organization (WHO) estimated the prevalence of STIs worldwide at 1.4 billion cases. The highest prevalence of cases, namely Herpes as many as 500 million cases, Human Papilloma Virus as many as 300 million cases, Hepatitis B as many as 240 million cases, Trichomoniasis as many as 156 million cases, Gonorrhea as many as 87 million cases, and Syphilis as many as 6.3 million cases. (Organization, 2019)

The prevalence of STIs is increasing every year and their spread is more evenly distributed throughout the world. The prevalence of STIs in South and Southeast Asia is 151 million cases, Africa is around 70 million cases, Australia and New Zealand is 1 million cases. Promiscuous and high-risk behavior is thought to be a factor that increases the prevalence of these STIs. (Diniarti \& Felizita, 2019)

From 2005 to 2011, Indonesia experienced an increase in the prevalence of Gonorrhea and Chlamydia infections by $179 \%$, Syphilis by $44 \%$, and HIV by 20,652 cases (Rahmi, 2015). From 2011 to 2018 there was an increase in HIV prevalence by 48,605 cases or $174 \%$ so that there was a tendency to increase prevalence every year, the prevalence of HIV cases in men was $27.6 \%$ higher than women. The prevalence of the age group infected with STIs is the highest, namely the age group 25-49 years at $70.4 \%$ and the age group 20-24 years at $15.1 \%$. The highest prevalence of risk factors for contracting STIs, namely clients of sex workers is $9.36 \%$, male sex workers are $6.94 \%$, male sex workers are $5.43 \%$, injecting drug users are $4.40 \%$, and female sex workers are $20.06 \%$. The highest prevalence of STIs infected work, namely employees 2,693 cases, unknown jobs as many as 1,837 cases, housewives with 1,576 cases, and entrepreneurs with 1,289 cases. (Aditama et al., 2011)

\section{Etiology}

STIs can be caused by a variety of causes. The list of causes or etiology of STIs can be seen in the following table: 
Nabilla Septiana, Dinie Ramdhani Kusuma, Yunita Hapsari / KESANS

Recognizing Sexually Transmitted Infections And Their Treatment

\begin{tabular}{|c|c|c|}
\hline No. & Causes of & Disease \\
\hline \multirow[t]{8}{*}{1.} & Bacteria: & \\
\hline & Neisseria gonorrhoeae, & Gonorrhea \\
\hline & Chlamydia trachomatis, & Chlamydiosis \\
\hline & Mycoplasma hominis & Epididymitis \\
\hline & Ureaplasma urealyticum & Urethritis \\
\hline & Treponema pallidum & Syphilis \\
\hline & Gardnerella vaginalis & Vaginitis \\
\hline & Donovania granulomatis & Granuloma inguinale \\
\hline \multirow[t]{6}{*}{2.} & Viruses: & \\
\hline & Herpes simplex virus & Herpes genitalis \\
\hline & Herpes B virus & Fulminant hepatitis \\
\hline & Human papillomavirus & Condyloma acuminatum \\
\hline & virus Molluscumcontangiosum & Molluscum contagiosum \\
\hline & Human immunodeficiency virus & AIDS \\
\hline \multirow[t]{2}{*}{3.} & Protozoa: & \\
\hline & Trichomonas vaginalis & Vaginitis \\
\hline \multirow[t]{2}{*}{4.} & Fungi: & \\
\hline & Candida albicans & Vulvovaginitis \\
\hline \multirow[t]{3}{*}{5.} & Parasites: & \\
\hline & Phthirus pubis & Pediculosis pubis \\
\hline & Sarcoples scabiei var.hominis & Scabies \\
\hline
\end{tabular}

Table 1. Etiology of STIs. (Menaldi, 2015) 


\section{Recognizing Sexually Transmitted Infections And Their Treatment}

STIs transmission can occur because of the interaction between the agent (diseasecausing factor), host (humans as the host), and the environment (factors). In addition, there are several risk factors for STIs transmission, namely heredity, free sex, condom use, blood transfusions, hygiene, socioeconomic, and culture. (Widyanthini et al., 2019)

\section{Risk Factors}

The increase in the incidence of STIs is influenced by several factors including demographic changes such as very high population growth, increased community movements due to work or tourism, advances in IT-based technology (Information Technology), and socioeconomic improvements. In particular, advances in IT-based technology have led to a borderless world, which can result in demographic changes resulting in a shift in moral and religious values in society. Other factors that also affect the increase in STIs are the state's negligence in providing health and sex education to the community, inadequate health facilities, and many asymptomatic cases so that sufferers do not feel sick, but can transmit the disease to others. (Tuntun, 2018)

\section{Clinical symptoms}

STIs that often occur in the community include syphilis, gonorrhea, trichomoniasis, condyloma acuminate, herpes simplex, and others.

- Syphilis

Clinical symptoms of Syphilis can be divided into three stages. First, the primary stage is characterized by the appearance of skin abnormalities on the external genitalia in the form of lenticular papules that erode and then become ulcers. The ulcer is round, solitary, the base is red and clean granulation tissue, and the walls are not resonant and palpable induration is called a durum ulcer. Second, the secondary stage is characterized by anorexia, weight loss, malaise, headache, low-grade fever, and arthralgia. Skin disorders are caused in the form of wet skin and are very contagious. Third, the tertiary stage is characterized by gum whose size varies from lenticular to as big as a chicken egg and the guma will soften until perforation occurs which then becomes an ulcer and seropurulent fluid comes out. In addition, there are abnormalities in the form of nodes that will form ulcers (Sitanala, 2019). 


\section{Recognizing Sexually Transmitted Infections And Their Treatment}

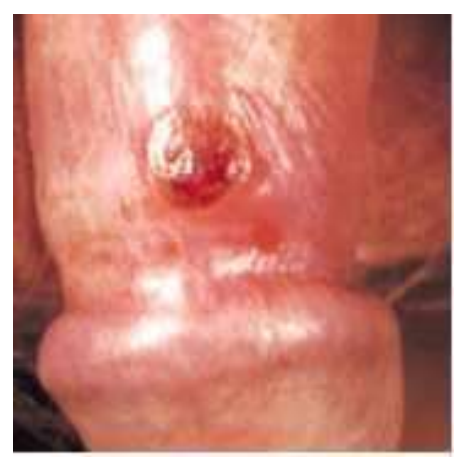

Figure 1. There is an ulcer with induration on a clean basis (Sitanala, 2019).

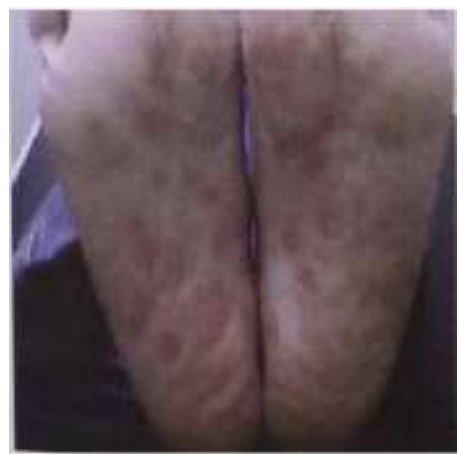

Figure 2. Secondary syphilis on the soles of the feet (Sitanala, 2019).

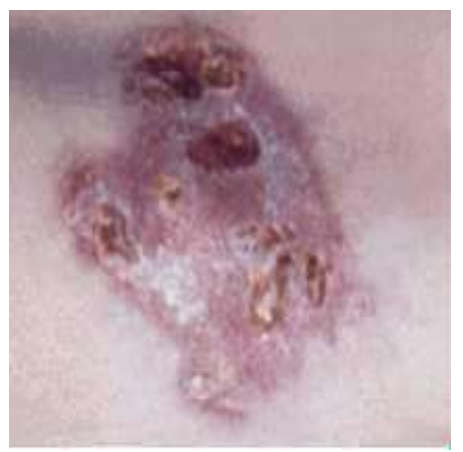

Figure 3. A tertiary syphilitic lesion with nodules with superficial ulceration (Sitanala, 2019).

- Gonorrhea

Clinical symptoms in women can be found in vaginal discharge that is purulent and slightly odorless, dysuria, intermenstrual bleeding, dyspareunia, and lower abdominal pain. In men, there may be urethritis, acute epididymitis, urethral stricture, rectal infection, and discharge from the end of the urethra, sometimes 


\section{Recognizing Sexually Transmitted Infections And Their Treatment}

accompanied by blood. In neonates, there may be a pain in the eyes, redness, and purulent pus (Sitanala, 2019). Subjective complaints in the form of itching, heat in the distal urethra around the external urethral orifice, can also be accompanied by pain during erection. On examination, the external urethral orifice mucosa appears hyperemic, edematous, and sometimes ectropion is found. (Batubara et al., n.d.)

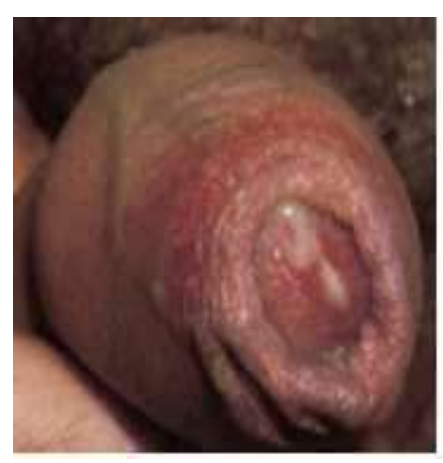

Figure 4. Overview of discharge in men (Sitanala, 2019).

\section{- $\quad$ Trichomoniasis}

Clinical symptoms of this trichomoniasis differ between women and men. In women, seropurulent to mucopurulent vaginal discharge may be yellowish, yellowgreen, odorless, and frothy. The vaginal wall will also appear red and swollen, can form small abscesses on the vaginal wall and cervix known as the strawberry appearance, and is accompanied by symptoms of dyspareunia, postcoital bleeding, and intermenstrual bleeding. In men, the clinical picture that occurs is generally lighter than in women, for example, dysuria, polyuria with mucopurulent urethral secretions. (Menaldi, 2015)

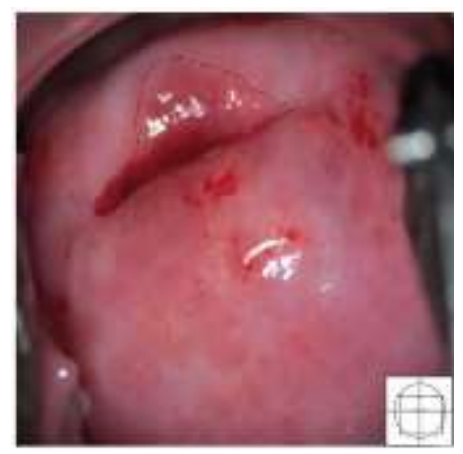

Figure 5. Strawberry appearance in trichomoniasis. (Norseth et al., 2014)

- Condyloma acuminata 


\section{Recognizing Sexually Transmitted Infections And Their Treatment}

Clinical symptoms in Condyloma acuminata are accompanied by a clinical form were the most frequently found are cauliflower-like lesions, colored like mucosa. While the clinical symptoms can be in the form of itching, if infected it causes pain, odor, and easy bleeding. (Menaldi, 2015)

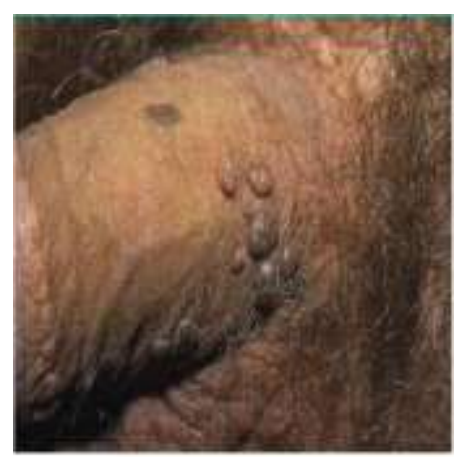

Figure 6. Condyloma acuminata in men (Sitanala, 2019).

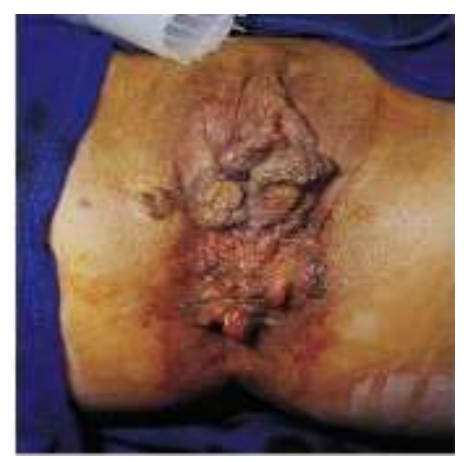

Figure 7. Condyloma acuminata in women (Sitanala, 2019).

- Herpes simplex

Clinical symptoms Herpes simplex progresses in three stages. First, the primary infection can be found in the form of vesicles that cluster on the skin that causes and is erythematous, filled with clear fluid, and then becomes seropurulent, can become crusted and ulcerated. May be accompanied by fever, malaise, and anorexia. Second, the latent phase where the patient does not feel clinical symptoms because the Herpes simplex virus is in an inactive state. Third, recurrent infections are often found with local prodromal symptoms before vesicles appear in the form of heat, itching, and pain. (Menaldi, 2015) 
Recognizing Sexually Transmitted Infections And Their Treatment

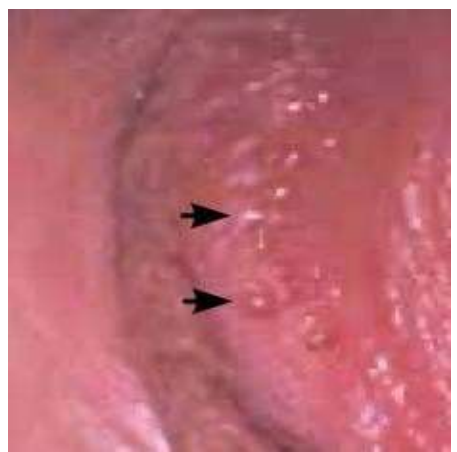

Figure 8. Vesicles on the vulva. (Leruez-Ville et al., 2020)

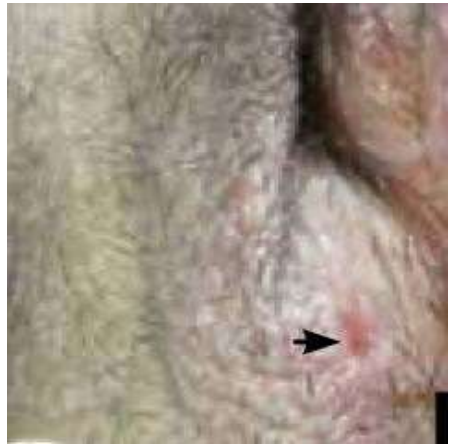

Figure 9. Ulcers on the vulva.(Leruez-Ville et al., 2020)

\section{Complications}

In pregnant women, complications that can occur in patients with trichomoniasis are premature rupture of membranes, premature birth, low birth weight babies, and pelvic inflammatory disease that can cause infertility. While complications in men that can occur are Epididymitis, Prostatitis, Infertility, and Prostate Cancer. (Daili et al., 2015) Gonorrhea infection in men can occur with local complications such as Tisonitis (inflammation of Tyson's gland), P Urethritis, Arthritis (inflammation of the Littre's glands), and Cowperitis (inflammation of the Cowper's glands). Complications in men can also spread to the ascending limb resulting in prostatitis, vesiculitis, funiculitis, epididymitis, trigonitis, terminal dysuria, and hematuria. In women can cause complications Salpingitis, a pelvic inflammatory disease that causes infertility or ectopic pregnancy. If the infection affects the urethra, Parautretritis can occur, and Bartholinitis can also occur in Bartholin's glands. (Daili et al., 2015)

\section{Management}

- Syphilis

Treatment is based on the duration of the infection and needs a longer treatment for infections that have lasted a long time. In general, benzathine penicillin $\mathrm{G}$ is the treatment of choice because blood levels of treponemal penicillin can last up to 21- 


\section{Recognizing Sexually Transmitted Infections And Their Treatment}

28 days. Can also be given some antibiotics that are not classified as penicillin such as doxycycline and erythromycin. (Daili et al., 2015)

\section{- Gonorrhea}

Many antibiotics are safe and effective to treat Gonorrhea, stop the chain of transmission, reduce symptoms, and reduce the likelihood of sequelae. The recommended treatment is a single dose of medication. The types of drugs recommended are cephalosporins, spectinomycin, kanamycin, thiamphenicol, and quinolones. Single-dose drugs that are no longer effective for treatment are tetracycline, streptomycin, and spiramycin. (Daili et al., 2015)

\section{- Trichomoniasis}

Metronidazole is the recommended drug and has been used for the treatment of Trichomoniasis for four decades. In addition, in 2004 tinidazole received FDA approval for the treatment of trichomoniasis. (Daili et al., 2015)

\section{- Condyloma acuminata}

Therapy only aims to eliminate or control the lesions of Condyloma acuminata chemically, physically or trigger an increase in the patient's immune system. Because it is self-limited, without treatment the lesions can disappear but the lesions can also persist or grow larger depending on the patient's immune response. Surgical procedures such as liquid nitrogen freezing and solution can also be performed trichloro-acetic acid (TCA) $80-90 \%$ if the lesion is in the vagina, liquid nitrogen froze surgery and podophyllin $10-25 \%$ if the lesion is in the urethral meatus, whereas if the lesion is in the urethra. the anus can be surgically incised. (Daili et al., 2015)

\section{- Herpes simplex New}

Lesions may be treated with topical medicated ointments containing idoxuridine preparations or containing acyclovir preparations in combination with oral treatment with acyclovir preparations. Meanwhile, to prevent recurrence which aims to increase cellular immunity, Lupton H (for type I VHS) and lupidon G (for type II VHS) preparations can be given in one treatment series. (Menaldi, 2015) 
Nabilla Septiana, Dinie Ramdhani Kusuma, Yunita Hapsari / KESANS

Recognizing Sexually Transmitted Infections And Their Treatment

\section{Conclusion}

Sexually Transmitted Infections (STIs) are diseases that can be transmitted from one person to another, can be caused by bacteria, viruses, parasites, and fungi. STIs can be transmitted through vaginal, anal, and oral sex. The prevalence of STIs is increasing every year and their spread is more evenly distributed throughout the world. Promiscuous and high-risk behavior is thought to be a factor that increases the prevalence of these STIs. STI transmission can occur because of the interaction between the agent (diseasecausing factor), the host (humans as the host), and the environment environmental (factors). STI diseases that often occur in the community include syphilis, gonorrhea, trichomoniasis, condyloma acuminate, herpes simplex, and others. STI management is given based on the cause of the STI, if it is caused by bacteria, give antibiotics, if it is caused by a virus, give antivirals, and if it is caused by fungi, give antifungals. 
Nabilla Septiana, Dinie Ramdhani Kusuma, Yunita Hapsari / KESANS

Recognizing Sexually Transmitted Infections And Their Treatment

\section{REFERENCES}

Daili, S.F. \& Nilasari, H., (2018), Gonore dalam Menaldi, S.L.S.W., Ilmu Penyakit Kulit dan Kelamin, Edisi 7, Badan Penerbit, FKUI.

Daili, S.F. \& Zubier, F., (2018), Tinjauan infeksi menular seksual (I.M.S). dalam Menaldi, S.L.S.W., Ilmu Penyakit Kulit dan Kelamin, Edisi 7, Badan Penerbit, FKUI.

Diarti, F., Felizita, E., dan Hasanudin. (2019). Hubungan Pengetahuan Dengan Kejadian Infeksi Menular Seksual di Puskesmas Penurunan Kota Bengkulu Tahun 2018. Journal of Nursing and Public Health. Vol. 7 No. 1.

Indriatmi, W. (2018). Herpes Simpleks. dalam Menaldi, S.L.S.W. Ilmu Penyakit Kulit dan Kelamin. Edisi 7. Badan Penerbit, FKUI.

Indriatmi, W. (2020). Sifilis. dalam Daili, S.F. Infeksi Menular Seksual. Edisi 5. Badan Penerbit, FKUI.

Karita, H.S., Wald, A. (2017). Genital herpes: Diagnostic and management considerations in pregnant women. Journal OBG Management. Vol. 29 No.11.

Kementerian Kesehatan Republik Indonesia. (2011). Pedoman Nasional Penanganan Infeksi Menular Seksual.

Kementerian Kesehatan Republik Indonesia. (2019). Profil Kesehatan Indonesia 2018.

Nilasari, H., Daili, S.F. (2020). Dalam Daili, S.F. Infeksi Menular Seksual. Edisi 5. Badan Penerbit, FKUI.

Norseth, H.M., Ndhlovu, P.D., et al. (2014). The Colposcopic Atlas of Schistosomiasis in the Lower Female Genital Tract Based on Studies in Malawi, Zimbabwe, Madagascar, and South Africa. Journal Atlas of Female Genital Schistosomiasis. Vol. 8 No. 11.

Puspita, L. (2017). Analisis Faktor Yang Berhubungan Dengan Kejadian Infeksi Menular Seksual Pada Wanita Pekerja Seksual. Jurnal Ilmu Kesehatan. Vol. 2 No. 1.

Rowawi, R., Djajakusumah, T.S. (2020). Daili, S.F. Infeksi Menular Seksual. Edisi 5. Badan Penerbit, FKUI. 
Nabilla Septiana, Dinie Ramdhani Kusuma, Yunita Hapsari / KESANS

Recognizing Sexually Transmitted Infections And Their Treatment

Sitanala, N.A. (2019). Karakteristik Pasien Infeksi Menular Seksual Tanpa Hiv di Puskesmas Jumpandang Baru Periode Januari 2018-Juni 2019, Online, Skripsi, http://digilib.unhas.ac.id/uploaded_files/temporary/DigitalCollection/OGM0YzYx ZTI1NmEwOTkwOWNiM2FhOTEwYTY1MDEwMzdiMDQ3YmM2MQ==.pdf (Diakses tgl 1 Desember 2020).

Tuntun, M. (2018). Faktor Resiko Penyakit Infeksi Menular Seksual (IMS). Jurnal Kesehatan. Vol. 9 No. 3.

WHO. (2019). Sexually transmitted infections (STIs). https://www.who.int/newsroom/fact-sheets/detail/sexually-transmitted-infections-(stis) (Diakses $\operatorname{tgl} 28$ November 2020).

Widyanthini, D.N., Widyanthari, D.M., dan Kurniasari, N.M.D. (2019). Kejadian Infeksi Menular Seksual di Kota Denpasar Tahun 2016. Jurnal Buletin Penelitian Kesehatan. Vol. 47 No. 4.

\section{Copyright holder :}

Nabilla Septiana, Dinie Ramdhani Kusuma, Yunita Hapsari (2021)

First publication right :

KESANS : International Journal Health and Science 